\title{
THE INFLUENCE OF BRAND IMAGE, HALAL LABEL, AND HALAL AWARENESS ON CUSTOMERS PURCHASING DECISION OF HALAL COSMETIC
}

\author{
Nadira Noor Utami ${ }^{1}$, Genoveva Genoveva ${ }^{2}$ \\ ${ }^{1}$ School of Business, President University, Cikarang \\ Email: nadiranoorutami@gmail.com \\ ${ }^{2}$ School of Business, President University, Cikarang \\ Email: genoveva@president.ac.id
}

\begin{abstract}
ABSTRAK
Kosmetik adalah elemen penting untuk kehidupan sehari-hari dan telah menjadi gaya hidup, terutama bagi wanita. Penggunaan kosmetik harus mematuhi peraturan keamanan pemerintah. Wardah adalah merek kosmetik yang dirancang dengan pengetahuan lokal dan berbahan alami. Wardah menerima Penghargaan Top Trademark Halal dalam kategori kosmetik, namun dari pra-survei terhadap Muslim milenial, terdapat 52,6\% responden tidak mempertimbangkan label halal dalam pembelian produk kosmetik. Tujuan dari penelitian ini adalah untuk menganalisis pengaruh citra merek, label halal, dan kesadaran halal terhadap keputusan pembelian pelanggan Wardah. Penelitian ini menggunakan data primer yang diperoleh dari distribusi kuesioner. Teknik pengambilan sampel dalam penelitian ini menggunakan metode random sampling. Jumlah sampel yang diperoleh 140 respondent, analisis data dalam penelitian ini menggunakan regresi linier berganda. Berdasarkan hasil penelitian penelitian ini, ditemukan bahwa salah satu variabel independen yaitu label halal yang ditandai oleh $\mathrm{X}_{2}$ tidak memiliki pengaruh signifikan terhadap variabel dependen, ditunjukkan oleh nilai-P>0,05. Itu bisa terjadi karena distribusi data tidak dapat mewakili sampel populasi. Untuk melanjutkan penelitian, diperlukan untuk melakukan intervensi dengan menghapus variabel tidak signifikan. Akhirnya setelah intervensi dilakukan, model regresi baru dapat memenuhi semua tes, dan akhirnya penelitian ini telah membuktikan bahwa variabel $\mathrm{X}_{1}$ dan $\mathrm{X}_{3}$ dapat menjelaskan variabel $\mathrm{Y}$ sebesar 32,6\% sedangkan 67,4\% lainnya dipengaruhi oleh faktor lain.
\end{abstract}

Kata Kunci: Citra Merek, Label Halal, Kesadaran Halal, Keputusan Pembelian, Kosmetik Halal

\begin{abstract}
Cosmetics are an important element for everyday life and have become a lifestyle, especially for women. Cosmetics consumption must be complying with government security regulation. Wardah is a cosmetic brand that is designed by local and natural knowledge. Wardah received the Halal Top Trademark Award in the cosmetics category, however from the pre-survey 52.6\% respondents did not consider halal labels in a cosmetics product. The purpose of this research study was to analyses the effect of brand image, halal label, and halal awareness on Wardah's customer purchasing decision. The research used a primary data obtained from the distribution of questionnaires. The technique of sampling in this research study is using random sampling method. The number of samples obtained by 140 people, data analysis in this research study is using multiple liner regression techniques. Based on the this research study result, it was found that one of the independent variables which is halal label marked by X2 has insignificance effected the dependent variable, it was shown by the P-value $>0.05$. That could happen because the distribution of the data cannot represent the sample of the the population. To continue the research it was required to conduct an intervention by removing the insignificant variable. Eventually after the intervention was conducted the new regression model were able to suit all the of the test, and eventually this research has proved that variable $X 1$ and X3 could explaine the Y variable by $32.6 \%$ while te other $67.4 \%$ was effected by other factors.
\end{abstract}

Keyword: Brand Image, Halal Label, Halal Awareness, Purchasing Decision, Halal Cosmetic

\section{INTRODUCTION}

\section{Research Background}

Muslim is a religion that guides human behavior in every aspect of life. One of the fundamental principles of Muslim religion is the behavior of human consumption. The Qur'an also refers to what is lawful and unlawful for human consumption (Al-Maidah: 3; Al-Baqarah: 173) Itani, 1983; Machali, A., \& Razak, 2013) say that the concept of halal is the key to consumption in the 
Muslim religion. Halal originated from the Arabic language of Halaal. It's said that the opponent is haram. In Islamic teaching, the word halal means "allowed". Usually, the term halal is used to refer to foods and beverages that can be consumed according to sharia. In Islam, Shari'a means the laws of Allah SWT that are issued to His servants through the Qur'an and Hadith. In general, al-Syari'ah means all Islamic teachings in the form of divine norms which are identical with addin (religion), which means that they cover all Islamic religious information (Ministry of Religion, 2003).

Indonesia, as a country whose majority population embraces Muslim religion, must pay attention to the food they consume, as well as to the choice of cosmetic products. Muslim consumers need information that the product is halal for consumption since Islamic sharia. Halal product is a priority in the implementation of all God's commands and prohibitions. Halal is an area in which it is cognitive, effective and co native for Muslims to comply with Islamic law (Wilson \& Liu, 2010). Central statistic bureau (BPS, 2017) show that Indonesia is the largest Muslim country. This fact makes Indonesia a potential market for the halal industry (Hunter, 2012).

\section{Research problem}

Wardah cosmetic emerged as the founder of the first halal cosmetics branded in Indonesia. As the halal brand, Wardah considered to be an innovation in the cosmetics industry as they implement new and specific internal and external operations that can fulfill consumer requirements (Mohezar, Zailani, \& Zainuddin, 2016). According Oscar \& Keni (2019) brand image has a strong and important impact on customer purchase decisions. However, from the pre-survey researchers found that $52.6 \%$ respondents (questionnaire, 2020) did not consider halal label in cosmetics product.

Muslim customers or entrepreneurs must be aware of the concept of halal in a commodity, both in terms of raw materials and processes. Halal awareness is the level of information that Muslim consumers possess to identify and consume halal products under Islamic law (Aziz \& Chok, 2013; Mutmainah, 2018). According to a survey conducted by Kasih Dia Consulting, the level of implementation among Muslim halal cosmetics was still low (Kamaruzaman, 2009). Based on the results of a study from Sharii \& Arifin (2010) and Kamilah \& Aniek (2017) found that the halal label was able to improve the Wardah brand image as a cosmetic product aimed at Muslim women, but had not been able to significantly influence consumers in their purchasing decisions. This finding is supported by (Rauschnabel et al. 2015) showed that the perception of halal labels on packaging, attitudes towards religion and brands, while the relative importance of the two antecedents depends on several consumer characteristics. Therefore, this research will be finding the brand image, halal label, and halal awareness influence on Wardah consumer purchase decision.

\section{LITERATURE REVIEW \\ Halal Cosmetic}

Halal cosmetics are products derived from halal materials and produced in accordance with the halal system used in certain parts of the body for the purpose of beautifying, cleaning, protecting and changing the appearance of the body (Sugibayashi et al., 2019). Why must use halal cosmetics? Because consuming food or using something that is lawful and good is an obligation for every Muslim according to (Surah Al-Baqarah / 2: 168) Itani, 1983. Provisions for consuming or using halal items also apply in wearing make-up and beauty or cosmetics.

The main different between halal cosmetic with the conventional one could be divided in three main things, starting from the cosmetic material, the making process, and the marketing. Based 
on Majelis Ulama Indonesia (MUI), halal cosmetic must not contain any material such as, halal animal placenta, feathers (hair, horns of animal carcasses), snails, worms, blood plasma, embrocated chicken eggs, cocoon / silkworm cocoons, and gold particles; therefore, if a cosmetic do contain one of the materials as mention before, it could be classified as conventional cosmetic or based on Islam law categorize as haram product. From a Muslim point of view, it is important to know the origin of raw materials and the manufacturing process of consumer goods because of the Sharia requirement to state that every Muslim must consume only halal and whole items. This situation is increasingly critical because the verification and authentication of halal products is of paramount importance in order to maintain the sanctity of the Muslim religion (Mursyidi, 2013).

Apart from those things, the concept of halal in the process of making also includes the treatment to the workers who contribute to the process. The Prophet Muhammad Sallallahhualaihiwasallam has given 5 (five) massages of how to treat the workers; 1) Give Wages Immediately, 2) Do not zalim on the wages, 3) Equal to the boss, 4) The boss should be Tawwadu' and 5) Not applicable hard and rude to subordinates (Itani, 1983).

According to the researcher opinion the last fullfilment of a cosmetic to be considered as halal cosmetic is while the marketing process of the halal cosmetic is accordance with the Islam law, there are actually no specific requirement for the marketing process that provided by Majelis Ulama Indonesia (MUI). The researcher have found some criteria that suitable for the case of marketing cosmetic. (Hasyim \& Iskandar, 2013) combines Philip Kotler's marketing mix theory with the Islamic concept into an Islamic marketing mix of 7P, are as follows; 1) Pragmatism \& product, 2) Pertinence \& promotion, 3) Palliation \& price, 4) Peer-support \& people, 5) Pedagogy \& physical environment, 6) Persistence $\&$ process and 7) Patience $\&$ place

\section{Brand Image}

According to Keller (2010), Brand image is "consumer perceptions and beliefs, as expressed in the relation retained in consumer memory," that is, customer perceptions and beliefs, as reflected in the association that occurs in the memory of the consumer with regard to the brand of a product that is seen, thought out and imagined. By creating the right image of the brand for a product, it will definitely be very helpful to the marketers, because the image of the brand will have an impact on consumer assessment of the expected alternative brands. Not only can meet the needs of consumers, but that is can provide better satisfaction and security. The better the brand image attached to the product, the more consumers will be interested in buying the product. As already mentioned by (Schiffman \& Kanuk, 2010), consumers will still select brands based on their image. If consumers do not have experience with a product, they appear to "trust" a favorite or well-known brand. Positive brand image has to do with customer loyalty, consumer confidence in positive brand value, and willingness to look for a brand. Positive brand identity also helps raise customer interest in competitive marketing activities. Oscar \& Keni (2019) concluded that brand image is a combination of memories about brands that are created and imprinted on consumers' minds. Consistent use of a brand by consumers can affect the use of a brand image consistently.

A brand in the market influences the ability of a company to analyze facts about how customers view brand identity, handle brand marketing strategies and communicate brand value to consumers (Mohammadzadeh, 2015). Brand image is the customer's perception of the product or the overall impression of the product produced in their minds (Eze et al, 2012). The indicators of brand image according to (Ratri, 2007) are as follows:

1. Product attributes, are things related to the brand itself, like packaging, taste, price, etc. 
2. Consumer benefits (consumer benefits), is the use of the product from that brand.

3. Brand personality, is an association concerning the personality of brand when brand it is human.

\section{Halal Label}

The Halal label are reflection of standard measures and religious fulfillment. According to Burgmann (2017), claimed that not only is halal subject to the food section, but halal denotation is often used in other non-food categories. Globally, the halal market is projected to be worth US $\$ 580$ billion per year and the halal food industry is expected to expand at $7 \%$ per year. Halal growth status can be related to religion and perception that it is safer, healthier, and tastier (Aziz \& N.V. Chok, 2015). In general, a minimum label must contains the name or brand of the product, raw materials, additional ingredients, nutritional information, expiration date, product contents, and legality information (Apriyanto \& Nurbowo, 2003)

Halal comes from the Arabic language Halal. The opponent is said to be haram. In Islamic teachings, the word halal means "allowed" or permitted. Usually, the word halal is used to refer to food and drinks that can be consumed according to shariah. At present, awareness for Muslims in the world to consume products labeled as halal is very high (Sucipto, 2017).

Halal is not only applicable to the food segment, but halal denotation is often used for other nonfood segments (Burgman, 2017). Based on these statements, the researchers concluded that the non-food segment in question could also be cosmetic. Nonfood products such as cosmetic materials have to comply with the Halal concept because, in particular, Muslims are becoming more halal conscious. Before making any purchase, they will distinguish a halal label. Ingredients for specific products should be specified in detail as they serve as a guide for nonhalal objects (Aziz \& N.V. Chok, 2015).

Indonesia is one of the nations within the world where the government gives full back in advancing the halal certification handle on items and administrations. Consequent to the halal certification, Indonesia has developed halal certification as the overall quality wellbeing and clean framework in embracing strategy for butchering handle and other related operations as endorsed by Islamic wards. The certification isn't constrained to the poultry and meat as it were; it moreover covers consumers' things such as makeup, pharmaceuticals, and toiletries. Nourishment producers and makers are required to comply with the benchmark guidelines of Danger Examination Basic Control Point (HACCP), Great Fabricating Hones (GMP), Great Sterile Hone (GHP), and ISO 9000 in arrange to meet halal necessity.

Halal information on products in Indonesia is in the form of a halal label that is certified by the Food and Drugs and Cosmetic Assessment Institute of the Indonesian Ulema Council (LP POM MUI) in cooperation with the Ministry of Health and the Ministry of Religion (Sukmawati, 2015).

\section{Halal Awareness}

Muslims believe that consuming halal food will be a blessing and health for humans, the same belief also applies to the cosmetic products used. It is an indicator of halal awareness of consumers. Islam teaches us to always consume everything on earth that is halal and good, food, drink and other products. Halal is a Muslim religious teaching have become the lifestyle of Muslim consumers in the world. As the Muslim population grows, awareness of the use of halal products also grows. Awareness is the capacity to perceive experience and be conscious of things and objects. It is a term that includes comprehension and interpretation of events or subjects. Awareness has been believed to be a significant factor in deciding the decision to select. In their 
research, (Golnazet al. 2010) found that awareness of halal values and halal food items is influenced by a positive attitude.

Consistent with the TPB (Theory Plan Behavior), consumers who have a favorable attitude would conduct the action of consuming or purchasing halal product in the sense of the current study. Empirical evidence presented by (Lada et al. 2009) in their halal product analysis has shown that perceptions are positively linked to the decision to select halal products.

(Alam \& Sayuti, 2011) have published similar results for a study of marketing students at one of the universities in Malaysia. Accordingly, the results of (Lada et al. 2009) have confirmed that the decision to select a halal product is decided by a positive attitude. In the context of the current research, the favorable understanding of halal concept and halal awareness is a positive attitude.

\section{Purchasing Decision}

Purchasing decision is a process that is carried out by consumers to fulfill their needs in order to obtain satisfaction with the highest value. According to (Fiani \& Japarianto, 2012) decision making by consumers to purchase a product begins with an awareness of the fulfillment of needs and desires (Haque et al, 2015).

Purchase decisions taken by consumers may occur if the customer has received services from the provision of services and consumers feel satisfied and dissatisfied (Wibowo \& Soedjono, 2014). Consumers must take decisions when acting; consumer purchasing decisions can be influenced by a number of factors. Consumers who have decided to buy the goods will experience satisfaction and re-purchase. Here are the elements for measuring consumer satisfaction (Kotler \& Keller, 2012):

1. Overall customer satisfaction as to how satisfied they are with the company's products.

2. Interest in repurchase, as customers buy back the goods of the company.

3. Willingness to recommend where willingness to suggest a product to a friend or family is an essential indicator of research and follow-up.

If business people want to market their goods effectively, they must consciously influence customers on the advantages and prices of the products they offer because they can influence potential buyers in the decision-making process (Nofiawaty \& Yuliandi, 2014).

\section{RESEARCH METHODOLOGY}

The purpose of the research design in social science research, collecting data relevant to test a hypothesis, evaluate a system or accurately characterize a phenomenon (Tabachnick \& Fidell (2013). Based on a predetermined research topic at the beginning of the research, the researchers have decided to use quantitative research with questionnaire for collecting the data. The population have specific qualities and characteristics to be learned and concluded by researchers (Sujaweni, 2014; Sugiono, 2013). In this research the population is the millennials (Y) and Z generation who use the halal cosmetics. Based on the Hair et al. (2010) the minimum sample size in this research is $\mathrm{N}=5 \mathrm{x}$ q (questions), since the questionnaire 27 questions, therefore the minimum sample size would be 140 respondents. Researchers use non-probability sampling is often associated with qualitative research (Zikmund, 2002; Yin, 2003). 


\section{RESULTS AND DISCUSSION \\ Validity and Reliability Test}

Researchers starting the data analysis with use 30 respondents for validity and reliability test. All of the questions valid with range $0.56-0.85>0.361$ (r-table), its mean that the data can be use for the next process. The reliability test also shown the same result, while $\mathrm{X}_{1}$ (Brand Image) is $0.85, \mathrm{X}_{2}$ (Halal Label) is $0.91, \mathrm{X}_{3}$ (Halal Awareness) is 0.84 and $\mathrm{Y}$ (Purchasing Decision) is 0.91 , all of the result $>0.7$ (Cronbach Alpha), which means that all of the variables is reliable (Ghozali \& Iman, 2011).

\section{Classical Assumption Test}

In table 1 residuals are normally distributed because the $p$-value $=0.088>\alpha=0.05$ (Ghozali $\&$ Iman, 2011). Based on the results of the normality test using a normal probability plot that shows below, graph shows that the pattern of points on the graph is seen to spread around the diagonal line and follows the direction of the diagonal line, so it can be concluded that the data is normally distributed, then the regression model used in the study meets the normality assumption.

Table 1. Normality Test

Source: SPSS Ver.21, 2020

\begin{tabular}{cc}
\hline D-value & $\boldsymbol{p}$-value \\
\hline 0.106 & 0.088 \\
\hline
\end{tabular}

Based on the multicollinearity test results the tolerance value of the Brand Image and Halal Awareness variables all show more than 0.1. While the VIF value of the Brand Image and Halal Awareness variable shows less than 10. Thus, between the Brand Image and Halal Awareness variables do not occur multicollinearity because the value of tolerance is more than 0.1 and the VIF value is less than 10 (Ghozali \& Iman, 2011). Scatterplot image shows that the points spread randomly and do not form patterns or specific lines. Then it can be concluded from the results of the test showing the variables tested in this study indicate that it has a good regression method and does not have the heteroscedascity pol in the regression model (Susanto, 2001). Linearity variable of Brand Image is 0.00, Halal Awareness is 0.003 is also $<0.05$, it can be concluded that Brand Image and Halal Awarenes on Purchasing Decision variables there is a linear relationship.

\section{Respondents Profile}

Table 2 shown that the respondent mostly from generation $\mathrm{Z}$ and millinnials generation which has $79 \%$ come from 16-25 years old, $15 \%$ come from $>25$ - 35 yeals old and small size respondents is $7 \%$ come from $>35 \%$ years old. By domicile, mostly they are from Jabodetabek $(65 \%)$, this data inline with the counter dan Wardah shops that distribute around $70 \%$ in Jabodetabek area. We got 14\% from Java (outside of Jabodetabek area), from Sumatera 9\%, Kalimantan $7 \%$ and others (NTT, NTB, Sulawesi) is $5 \%$.

Table 2. Respondents Profile

Source: SPSS Ver.21, 2020

\begin{tabular}{lcc}
\hline \multicolumn{1}{c}{ Age } & Total & Percentage \\
\hline $16-25$ years old & & $79 \%$ \\
\hline$>25-35$ years old & & $14 \%$ \\
\hline$>35$ years old & & $7 \%$ \\
\hline \multicolumn{2}{l}{$\mathbf{1 4 0}$} & $\mathbf{1 0 0 \%}$ \\
\hline Domicile & & \\
\hline
\end{tabular}




\begin{tabular}{|c|c|}
\hline Jabodetabek & $65 \%$ \\
\hline Java (outside of Jabodetabek) & $14 \%$ \\
\hline Sumatera & $9 \%$ \\
\hline Kalimantan & $7 \%$ \\
\hline Others & $5 \%$ \\
\hline 140 & $100 \%$ \\
\hline
\end{tabular}

\section{Regression Analysis and Hipothesis Testing}

Based on the coefficient of parameter $\mathrm{X}_{2}$ is not significant, an intervention is carried out by removing the $X_{2}$ variable and then retesting the regression model without the $X_{2}$ variable. After going through all stages of pre-normality testing and testing classic assumptions, then this regression model is considered feasible as a basis for decision making in hypothesis testing this research.

Table 3. Multiple Regression Result

Source: SPSS Ver.21, 2020

\begin{tabular}{|c|c|c|c|c|c|c|}
\hline & \multirow[b]{2}{*}{ Model } & \multicolumn{2}{|c|}{ Unstandardized Coefficients } & \multirow{2}{*}{$\begin{array}{c}\text { Standardized } \\
\text { Coefficients } \\
\text { Beta } \\
\end{array}$} & \multirow[b]{2}{*}{$\mathrm{T}$} & \multirow[b]{2}{*}{ Sig. } \\
\hline & & $\mathrm{B}$ & Std. Error & & & \\
\hline \multirow[t]{3}{*}{1} & (Constant) & 1,234 & 2,419 & & .510 & .611 \\
\hline & $\mathrm{X} 1$ & .569 & .152 & .375 & 3,748 & .000 \\
\hline & $\mathrm{X} 3$ & .354 & .148 & .239 & 2,387 . & .018 \\
\hline
\end{tabular}

a. Dependent Variable: Y (Purchasing Decision), $\mathrm{X}_{1}$ : Brand Image, $\mathrm{X}_{3}$ : Halal Awareness

Based on the multiple regression results above, it can be obtained Regression equation is:

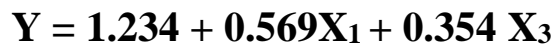

From the table 3 above we can conclude that, the regression coefficient of brand image $\left(\mathrm{X}_{1}\right)$ is $56.9 \%$ which means that brand image has the big contribution to Purchasing Decision than the other variable.

For hypothesis test, $\mathrm{X}_{1}$ (Brand Image) and $\mathrm{X}_{3}$ (Halal Awareness) have significant influence on $\mathrm{Y}$ (Purchasing Decision) with significant level < 0.05 (Nawari, 2010; Ghozali \& Iman, 2011).

Table 4. F-Test

Source: SPSS Ver.21, 2020

ANOVA $^{\mathrm{a}}$

\begin{tabular}{|c|c|c|c|c|c|c|}
\hline \multicolumn{7}{|c|}{$\mathrm{ANOVA}^{\mathrm{a}}$} \\
\hline Model & & $\begin{array}{l}\text { Sum of } \\
\text { Squares }\end{array}$ & Df & Mean Square & $\mathrm{F}$ & Sig. \\
\hline \multirow[t]{3}{*}{1} & Regression & 1005,101 & 2 & 502,551 & 33,071 & $.000^{\mathrm{b}}$ \\
\hline & Residual & 2081,892 & 137 & 15,196 & & \\
\hline & Total & 3086,993 & 139 & & & \\
\hline
\end{tabular}

Based on the results of the F statistical tests above by using analysis of variance or ANOVA can be seen with a significance value that the significance value $(0.000<0.05)$, which means 
significant, it can be concluded that the brand image variable $\left(\mathrm{X}_{1}\right)$ and halal awareness $\left(\mathrm{X}_{3}\right)$ simultaneously has a significant influence on product purchase decision variables (Y).

\section{Coefficient of Determination}

Table 5. Coefficient of Determination

Source: SPSS Ver.21, 2020

\begin{tabular}{l|l|l|l|r} 
& \multicolumn{2}{c}{ Model Summary } \\
Model & R & R Square & $\begin{array}{c}\text { Adjusted R } \\
\text { Square }\end{array}$ & $\begin{array}{c}\text { Std. Error of the } \\
\text { Estimate }\end{array}$ \\
\hline 1 &, $571^{\mathrm{a}}$ &, 326 & 316 & 3,89824 \\
\hline
\end{tabular}

a. Predictors: (Constant), $\times 3, \times 1$

The correlation between independent variables and dependent variable is strong because $57.1 \%$ > 50\% (Ghozali \& Iman, 2011). While Adjusted R square data shown that value 0.326 it means that variables $\mathrm{X}_{1}$ and $\mathrm{X}_{3}$ are able to explain the $\mathrm{Y}$ variable by $32.6 \%$, so it can be said that $32.6 \%$ of the $\mathrm{Y}$ variable is able to be explained by the model while the remaining $67.4 \%$ is influenced by other factors not included in the model.

\section{SUMMARY AND RECOMMENDATION}

The result of this study has some practical implication for the academic purpose. This research study served the knowledge about Brand Image, Halal Label, Halal Awareness and Purchasing Decision from different perspectives. Based on the data processing result, the Brand Image and Halal Awareness have significance on Purchasing Decision. This result inline with Aspan, 2017; Hidayat, 2018; Syahrivar \& Azizah, 2018. However, Halal Label has no significance on Purchasing Decision. Therefore, this research could be used as the reference for future research if there are conditions where one of the independent variables has insignificance with the dependent variable.

We found some problem during the research period, and the researchers suggested the government to simplify the bureaucracy provide more certificate expert auditor for conducting the audit. This rsuggestion are based on the fact that as is known, based on the Act the mechanism for submitting halal certificates is done by Business Actors in writing to the Halal Product Guarantee Agency (BPJPH). Furthermore, the BPJPH establishes the Halal Inspecting Agency (LPH) to conduct inspection and or testing of the halal product. The halal product inspection and or testing are carried out by the Halal Auditor at the business location during the production process.

Furthermore, LPH submits the results of inspection and / or product halal testing to BPJPH to be submitted to the Indonesian Ulama Council (MUI) in order to obtain a product halal determination. MUI will hold a Halal Fatwa Session to determine the halal of the Product no later than 30 (thirty) working days from the receipt of the results of the inspection and / or product testing from the BPJPH. The decision to determine Halal Products will be submitted by MUI to BPJPH to be the basis for the issuance of Halal Certificates (LPPM BPOM, 2013).

To carry out the mandate of the Act, it is necessary to issue a Government Regulation for Halal Product Guarantee as a law implementing regulations. The halal-certified products supported by 
enacted Law no. 33 of 2014 concerning Halal Product Guarantee (Widyanto \& Irfanur, 2019). Hwever Government Regulation is not ready, the entire infrastructure under it also cannot work perfectly. The researchers found that this condition shows the lack of serious attention of the government to the halal industry, and the availability of halal products, according to the expectations of the community. The government in this case the Ministry of Religion seems to be hesitant to implement the Halal Assurance System according to the law.

For the next researchers, advertising variables can be added to objects that are different from what the researchers have done, so there is a better influence on purchasing decisions. Researchers also suggest that the next researcher can combine this research in other research which is also a research that has similar criteria with cosmetic products, so that it can be used in further research and perfects an understanding of the variables that influence each other.

\section{REFERENCES}

Alam, S. S., \& Sayuti, N. M. (2011). Applying the theory of planned behavior (TPB) in halal food purchasing. . International Journal of Commerce and Management, 21(1), 8-20.

Apriyantono, \& Nurbowo. (2003). Panduan Belanja dan konsumsi Halal. Jakarta: Khairul Bayan.

Aspan, H; Sipayung, I.M \& Ritongan, H.M (2017). The Effect of Halal Label, Halal Awarness, Product Price, and Brand Image to the Purchasing Decision on Cosmetic Products (Case Study on Consumers of Sari Ayu Martha Tilaar in Binjai City). International Journal of Global Sustainabilit. Vol.1(1), 56-66.

Aziz, Y., \& N.V. Chok. (2013). The Role of Halal Awareness, Halal Certification and Marketing Components in Determining Halal Purchasing Intention Among Non-Muslims in Malaysia; A structural equation modwling J. Int. Food Agribusiness Marketing. Vol. 25(1), 1-23.

Badan Pusat Statistik (BPS) (2017), Population by Region and Religion, [Online] https:// sp2017.bps.go .id/ index php/site/tabel?tid=321 (Accessed 20 April 2020).

Burgmann, T. (2017, July 22). Growing Muslim population pushing companies to produce products they can eat. Retrieved April 20, 2020, from www.thestar.com/Business/article/238551

Edze, U. C., Tan, C.-B., \& Yeo, A. L.-Y. (2012). Purchasing Cosmetic Products: A Preliminary Perspective of Gen-Y. Contemporary Management Research.

Fiani, \& Japarianto. (2012). Analisis Pengaruh Food Quality dan Brand Image Terhadap Keputusan Pembelian Roti Kecik Toko Roti Ganep's di Kota Solo. Jurnal Manajemen Pemasaran Vol 1(1), 1-6

Ghozali, \& Imam. (2011). Aplikasi Analisis Multivariate dengan Program IMB SPSS, Edisi 5. Semarang: Universitas Diponegoro.

Golnazet, R., Zainalabidin, M., Mad Nasir, S., \& Eddie Chiew, F. C. (2010). Non-Muslims' awareness of halal principles and related food products in Malaysia. International Food Research Journal, 17, 667-674.

Hair, J.F., Black, W. , Babin B., \& Anderson, R. (2010). Multibariate Data Analysis. New Jersey : Pearson.

Haque, A., Anwar, N., Yasmin, F., Sarwar, A., Ibrahim, Z., \& Abdul, M. (2015). Purchase intention of foreign products: A study on Bangladeshi consumer prespective. Sage Open, 5, 1-12.

Hidayat, A. P. (2018). Pengaruh Label Halal dan Kualitas Produk Terhadap Proses Keputusan Pembelian Produk Kosmetik Wardah Menggunakan Citra Merek (Brand Image) Sebagai Vaeiabel Intervening (Studi Kasus Pada Fans Page Facebook Wardah Kosmetik). 
COSMETIC

Hunter, M. (2012). The Emerging Halal Cosmetic. Arau, Malaysia: University Malaysia Perlis. Itany, Talal. (1983) “Quran English Translation Clear Easy To Read Pure English” A Edition: Clear Quran, Dallas USA.

Kamilah, G., \& Aniek, W. (2017). Pengaruh Labelisasi Halal dan Brand Image Terhadap Keputusan Pembelian Melalui Minat Beli. Jurnal Ilmu dan Riset Manajemen, Vol.6 (2),

Keller, K. L. (2010). Strategic Brand Management: Building, Measuring, and Managing Brand Equity. New Jersey: Pearson Education.

Kotler, P., \& Keller, K. (2012). Principles of Marketing. New Jersey: Prentice Hall.

Lada, S., Tanakinjal, H. G., \& Amin, H. (2009). Predicting Intention to Choose Halal Products using Theory of Reasoned Action. International. Journal Islamic and Middle Eastern Finance and Management, 2 (1), 66-76.

LPPOM MUI. (2013). Persyaratan Sertifikasi Halal. [Online] http://www.halalmui.org/newMUI/index. $\quad$ php/main/go_to_section/39/1328/page/1. (Accessed 25 April 2020)

Machali, M., A., R., \& Razak, L. (2013). The Effect of Halal Food Awareness on Purchase Decision with Religiosity as A Moderating Variable: A Study at Higher Education Institutions in Brunei Darussalam. Research paper.

Mohammadzadeh, R. (2015). The Effect of Brand Image and Purchase Intention on Cosmetic Products: Evidence from North Cyprus (Eastern Mediterranean University), Research paper.

Mohezar, S., Zailani, S., \& Zainuddin, Z. (2016). Halal cosmetics adoption among young Muslim consumers in Malaysia: Religiosity concern. Global Journal Al-Thaqafah, 6(1), 47-59.

Mursyidi, A. (2013). Chemical Analysis Authentication Role in Halal and Food Pharmaceutical Products. Journal of Food and Pharmaceutical Science. Vol.1, 1-4.

Mutmainah, Lu'liyatul .(2018). The Role of Religiosity, Halal Awareness, Halal Certification, and Halal Food Ingredients on Purchase Intention of Halal Food. Journal of Islamic Economics, Finance and Banking : Ihftifaz. Vol.1(1), 33-50

Nawari. (2010). Analisis Regresi Dengan MS Excel 2007 dan SPSS 17. Jakarta: PT Elex Media Komputindi.

Nofiawaty, \& Yuliandi, B. (2014). Pengaruh Store Atmosphere Terhadap Keputusan Pembelian Konsumen pada Outlet Nyenyes Palembang. Jurnal Manajemen dan Bisnis Sriwijaya, 12 (1), 56- 73.

Oscar, Y \& Keni, K. (2019). Pengaruh Brand Image, Persepsi Harga, dan Service Quality terhadap Keputusan Pembelian Konsumen. Jurnal Muara Ilmu Manajemen dan Bisnis, $3(1), 20-28$.

Questionnaire (2020). The Influence of Brand Awareness, Halal Label, and Halal Awareness on Customers Purchasing Decision on Halal Cosmetics. Bekasi : arranged by researchers.

Ratri, L. E. (2007). Relationship Between Brand Image operator cell with Brand loyalty to students that use a cell phone (Study Case to faculty of Economic regular University Diponegoro). Research paper.

Rauschnabel, P. A., Herz, M., Schlegelmilch, B. B., \& Ivens, B. S. (2015). Brands and religious labels: a spillover perspective. Journal of Marketing Management. Taylor \& Francis, Vol.00, 1-25.

Ministry of Religion of the Republic of Indonesia (2017). [Online] https://kemenag.go.id (Accessed June 2020)

Schiffman, L. G., \& Kanuk, L. (2010). Consumer Behavior. New Jersey: PrenticeHallInternational, Inc. 
Shaari, J. A., \& Afin, N. S. (2010). Dimension of halal purchase intention: a preliminary study. International Review of Business Research Papers, 6 (4), 444-456.

Sucipto. (2017). Halal Dan Haram Menurut Al-Ghazali Dalam Kitab Mau'idhotul Mukmin. Jakarta : Maghfirah Pustaka.

Sugibayashi, K., Yusuf, E., Todo, H., Dahlizar, S., Sakdiset, P., Arce, F. J., \& See, G. L. (2019). Halal cosmetics: A review on ingredients, production, and testing methods. Cosmetics.Vol.6(3), 1-17.

Sugiyono. (2013). Perilaku Konsumen (Seri 2). Bogor: Ghalia Indonesia.

Sujarweni V. W. (2014). Research Methodology (1st Ed.). Yogyakarta Gava Media.

Sukmawati, L. (2015). Analisis Pengaruh Label Halal Terhadap Brand Switching (Kasus Produk Kosmetik Wardah). Institut Pertanian Bogor.

Susanto, K. (2001) Manajemen Pemasaran Indonesia. Jakarta: Salemba Empat.

Syahrivar, J., \& Azizah, P. A. (2018). The role of religiosity and brand perception in the brand preference for halal cosmetics: a case study of family-owned Islamic cosmetic business. International Journal of Technology Transfer and Commercialisation, 16(2), 146-158.

Tabachnick, B. G. \& Fidell, LS (2013). Using Multivariate Statistics. Pearson New International Editon

Widyanto, H.A \& Irfanur, M.K (2019). Faith-Based Marketing: Antecendents of Purchase Intention for Halal Certified Personal Care Products. Jurnal Muara Ilmu Ekonomi dan Bisnis, 3(2), 421-430.

Wilson, J.A.J and Liu, J (2010). Shaping the Halal into a Brand. Journal of Islamic Mrketing. Vol.1(2). 107-123.

Wibowo, A., \& Soedjono. (2014). Pengaruh Kualitas Layanan, Harga dan Lokasi Terhadap Keputusan Pembelian di

Yin, R. K. (2003). Case study research, design and methods Business research methods. Third Edition. California : Sage Publication.

Zikmund, (2002). Business research methods, Dryden. Thomson Learning. 